\title{
"Pilgrimage Tourism of Shegaon Town: A Study With Respect To Geographical Perspective And Purpose of Visit" .
}

\author{
Mr. Ashok Shamrao Patil , Dr. K. A. Mali \\ Department of Geography Rajarshi Shahu Arts and Commerce College, Rukadi Tal. Hatkanangael \\ Dist Kolhapur. Department. of Geography Rajaram College Kolhapur.

\begin{abstract}
The Shegaon is very famous and pious place in Maharashtra state with respect to Pilgrims. Every year many pilgrims take Darshan of Shri. Sant.GajananMaharaj, Samadhi and get blessings. The place is very busy during certain period of the year and local bodies have to manage theses by providing various facilities with minimum cost. The Researcher has studied the tourism with respect to various criteria of pilgrims and useful information is generated to provide it to Government Authorities for decsiosn making and planning various activities during the festival season. The main intention is to increase the revenue of the Sanstha and local body of the Shegaon with very decent and best services provided to pilgrims visiting the pious place. The Researcher has used very systematic methods to study all the facilities provided and data is collected personally to find out the status. Presentation and Analysis is done by Tables and Graphs to get better feel of the facility provided
\end{abstract}

KEYWORDS:- Tourism, Pilgrims, culture, history, Holy places.

\section{INTRODUCTION}

The paper highlights on pilgrims at Shegaon in India . Religion is a base rock of the human society and it comes with every one by their birth and it becomes their social identity even the way of life. So religion is a shape of society which indicates several types of cultural custom in the human being. India is a big country in the world living together various types of religions. There is good admiration to every religion so it is known as a secular country in the world. India's having tremendous history about numerous religions and their origin in the Indian continent

Religious holy places are a main base of the pilgrimage tourism and in India having number of holy places, which is famous for the pilgrimage tourism. For the present study Shri. Sant.GajananMaharaj, Samadhi place has taken for the present study which is well known for the Hindu holy place in Maharashtra.

\section{STUDY REGION}

The Shegaon has taken for the present study and whic is located in the northern part of Buldana district of Maharashtra in India. It is lies between $20^{\circ} 28^{\prime}$ North Latitudes and $76^{\circ} 68^{\prime}$ East longitudes and located in the Purna basin. It has an average elevation of 275 meters ( 905 feet). Shegaon`s maximum temperature during summer is $40^{\circ} \mathrm{C}$ and in winter $19^{\circ} \mathrm{C}$. It is located around 550 K.M.east from Mumbai and 300 K.M.west from the Nagpur. Shegaon is a municipality and also place of tehsil in Buldana District. It has acquired fame as a pilgrimage center because ShriGajananMaharajSansthan is the biggest temple trust in the vidarbharegion. AnandSagar area is developed by ShriGajananMaharaj Temple Trust on about 350 acres of land as spiritual as well as entertainment center for devotees coming to Shegaon.

\section{OBEJECTIVES}

1. To study of pilgrimage tourism in Shegaon town of Buldhana district.

2. To analyze spatial distribution of Shegaon pilgrims.

\section{DATA BASE AND METHODOLOGY}

The present study is based on primary data source which is collected by the intensive field work visiting Shegaon and through the schedule and interview techniques.

Data and information of pilgrims isanalyzed on the basis of spatial distribution, education, religion, mode of travel, Occupation, income, purpose of visit, etc have analyzed by use of statistical and cartographic techniques like pie diagram, bar graph etc. 
V. A SPATIAL DISTRIBUTION OF SHEGAON PILGRIMS:

Shegaon is a Hindu religious center therefore there are large number of pilgrims are coming for the worship of Shri Sant Gajanan Maharaj Samadhi and which is one of the best pilgrimage center in Maharashtra so its spatial study has made in the present paper as fallow.

VI.

MODE OF TRAVEL OF SHEGAON PILGRIMS:

There are large number of pilgrims come with several types travel mode such bus, Railway, own car etc. The study of the travel mode of shegaon pilgrims have distributed into seven category shown into following table. There is large number of pilgrims visited with their own car and which is counted about 28.5 percent. Various pilgrims have come by the Railways and which is counted about 23.2 percent this types of pilgrims have in the second rank of the percentage because of the very reasonable and good facilitate journey in the Shegaon.

\section{MODE OF TRAVEL OF SHEGAON PILGRIMS}

\begin{tabular}{|l|l|l|l|}
\hline \multicolumn{4}{|c|}{ Mode of Travel } \\
\hline Sr. No & \multicolumn{1}{|c|}{ Mode of Travel } & $\begin{array}{c}\text { No. Of } \\
\text { Pilgrims }\end{array}$ & Percentage \\
\hline 1 & Private Bus & 81 & 12.62 \\
\hline 2 & Motor Cycles & 31 & 4.86 \\
\hline 3 & Own Car & 183 & 28.5 \\
\hline 4 & Rental vehicle & 121 & 18.84 \\
\hline 5 & M.S.R.T.C Buses & 64 & 9.96 \\
\hline 6 & Railways & 149 & 23.2 \\
\hline 7 & Other & 13 & 2.02 \\
\hline & Total & 642 & 100 \\
\hline
\end{tabular}

Source: Compiled by Author

PILGRIMS MODE OF TRAVEL

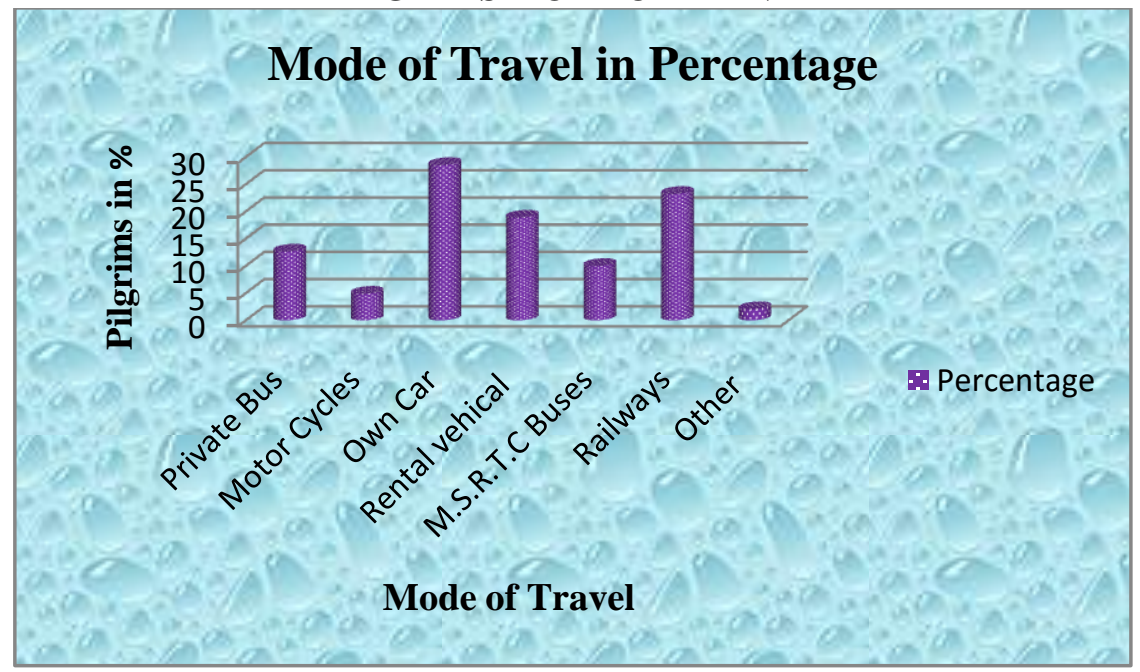

The rental vehicle pilgrims counted with the 18.84 percent and 12.62 pilgrims are visited with private bus to the Shegaon. The table shown 9.96 percent pilgrims traveled by M.S.R.T.C. Buses after that 4.86 percent pilgrims visited by their Motor Cycles and 2.02 percent pilgrims visited by other types of vehicles at shegaon. 
VIII.

EDUCATIONAL QUALIFICATION OF PILGRIMS: following table.

In the study educational qualification of pilgrims has taken into consideration and it is shown into

EDUCATIONAL QUALIFICATION OF PILGRIMS

\begin{tabular}{|l|l|l|l|}
\hline \multicolumn{4}{|l|}{ Educational Qualification of Pilgrims } \\
\hline $\begin{array}{l}\text { Sr. } \\
\text { No. }\end{array}$ & Educational Qualification & $\begin{array}{l}\text { No } \\
\text { Pilgrims }\end{array}$ & Percentage \\
\hline 1 & Illiterate & 42 & 6.54 \\
\hline 2 & Primary & 87 & 13.55 \\
\hline 3 & Secondary & 225 & 35.06 \\
\hline 4 & College & 288 & 44.85 \\
\hline & TOTAL & 642 & 100 \\
\hline
\end{tabular}

Source: Compiled by Author

Educational qualification of pilgrims is divided into four categories and which is Illiterate, Primary educated, Secondary educated and College attended pilgrims including graduate and post graduated pilgrims respectively. The above table Clearly shown large number of pilgrims have studied up to college attended education included graduate and postgraduate and which is counted about 45 percent with the highest range amount the all category.

EDUCATIONAL QUALIFICATION OF PILGRIMS

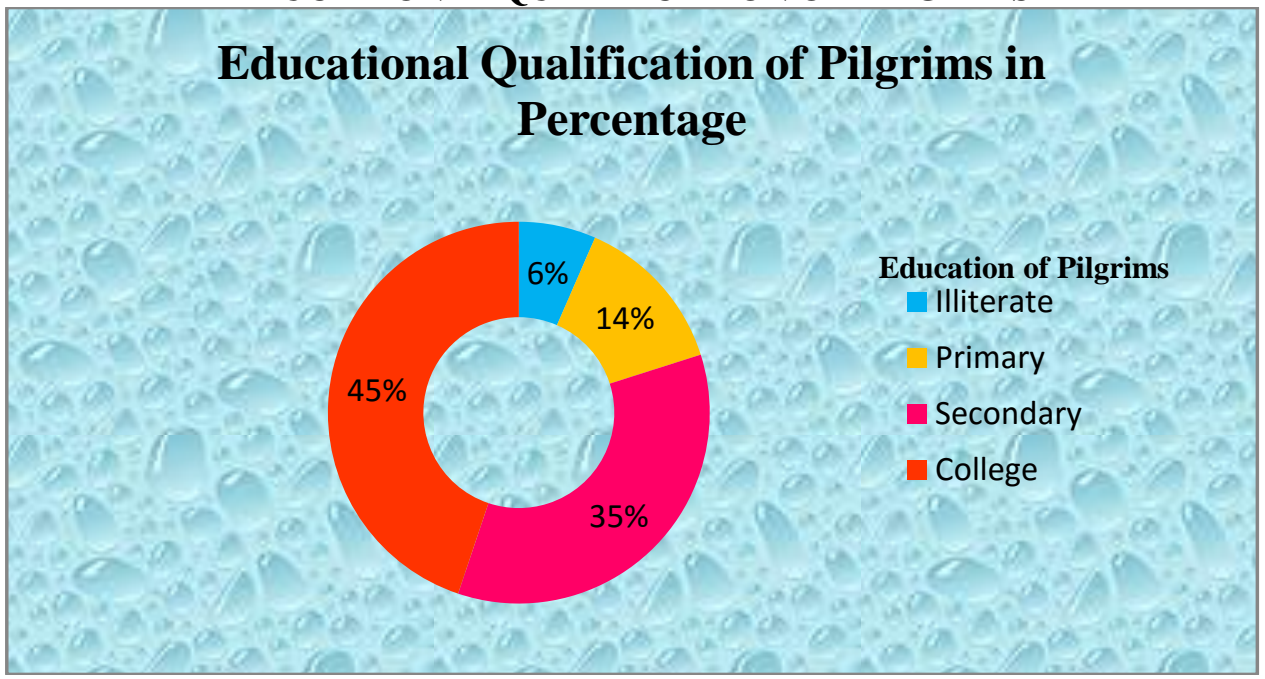

In the second range Secondary educated pilgrims are counted with 35 percent and after that primary educated pilgrim counted with 14 percent respectively. The illiterate educated pilgrims counted about 6 percent and which is lowest range in the educational study of the Shegaon pilgrims.

IX.

OCCUPATIONAL STRUCTURE OF PILGRIMS:

The occupational structure of pilgrims has shown in the following table into five categories.

Occupational structure of pilgrims has divided into five category and which are government servant, Private Services, Agriculture, Trade and Commerce and Other respectively. There is noticed 29 percent pilgrims engaged with Private Service and this is highest range among the occupation of the pilgrims

$\mathbf{X}$.

OCCUPATIONAL STRUCTURE OF PILGRIMS Occupational Structure of Pilgrims

\begin{tabular}{|l|l|l|l|}
\hline $\begin{array}{c}\text { Sr. } \\
\text { No. }\end{array}$ & \multicolumn{1}{|c|}{ Occupations } & \multicolumn{1}{|c|}{ No. of. Pilgrims } & Percentage \\
\hline 1 & Government Servant & 99 & 15.42 \\
\hline 2 & Private Service & 186 & 28.98 \\
\hline
\end{tabular}




\begin{tabular}{|l|l|l|l|}
\hline 3 & Agriculture & 124 & 19.31 \\
\hline${ }^{4}$ Source: Compiled by Author & Trade and Commerce & 174 & 27.1 \\
\hline 5 & Other & 59 & 9.19 \\
\hline & Total & 642 & 100 \\
\hline
\end{tabular}

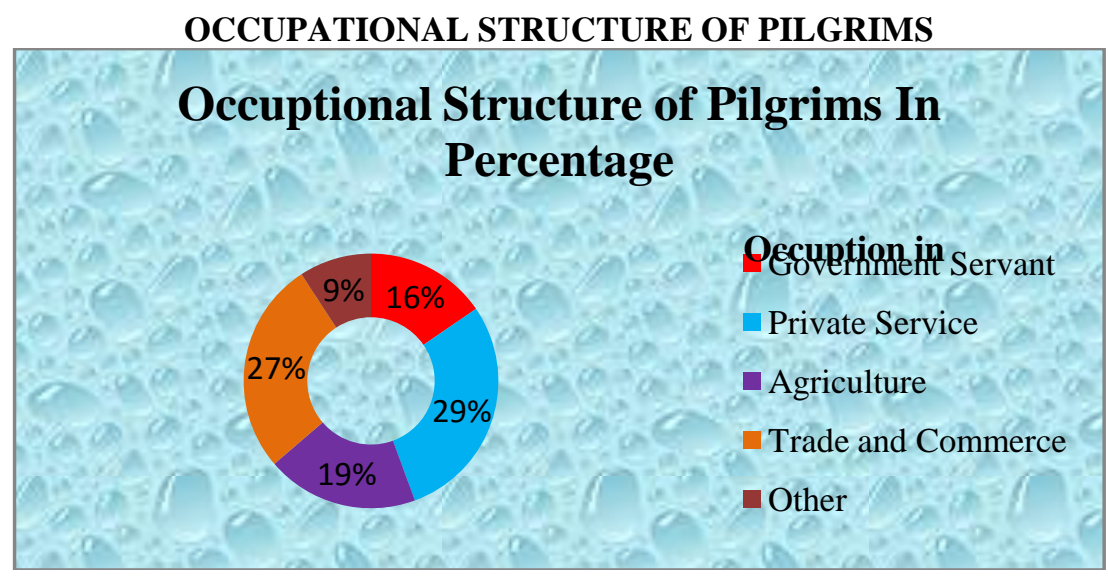

The trade and commerce is counted with the 27 percent and after that Agricultural pilgrims is noticed with 19 percent and government servant are observed with 16 percent and 9 percent and which is lowest range of the occupational structure of Shegaon pilgrims.

\section{XI.}

INCOME OF PILGRIMS

The level of income of the Shegaon pilgrims is assed and divided in to five categories and which have shown into following table.

Income of Pilgrims

\begin{tabular}{|l|l|l|l|}
\hline \multicolumn{4}{|c|}{ Income of Pilgrims } \\
\hline $\begin{array}{c}\text { Sr. } \\
\text { No }\end{array}$ & \multicolumn{1}{|c|}{ Income Group } & $\begin{array}{c}\text { No. Of. } \\
\text { Pilgrims }\end{array}$ & Percentage \\
\hline 1 & Up to 25,000 & 51 & 7.94 \\
\hline 2 & 26,000 to 50,000 & 96 & 14.95 \\
\hline 3 & 51,000 to 75,000 & 153 & 23.83 \\
\hline 4 & 76 to 1,00,000 & 138 & 21.49 \\
\hline 5 & Above 1 Lakh & 204 & 31.79 \\
\hline & Total & 642 & 100 \\
\hline
\end{tabular}

Source: Compiled by Author

The pilgrims income level is divided in five categories in rupees and which is up to $25,000 /-, 26$ to 50,000, 51 to $75,000,75$ to $1,00,000$, and above 1 lakh respectively. There is noticed maximum pilgrims are into above one lakh annual income and they are noticed with 31.79 percent including in that various government servant, and mostly businessmen.

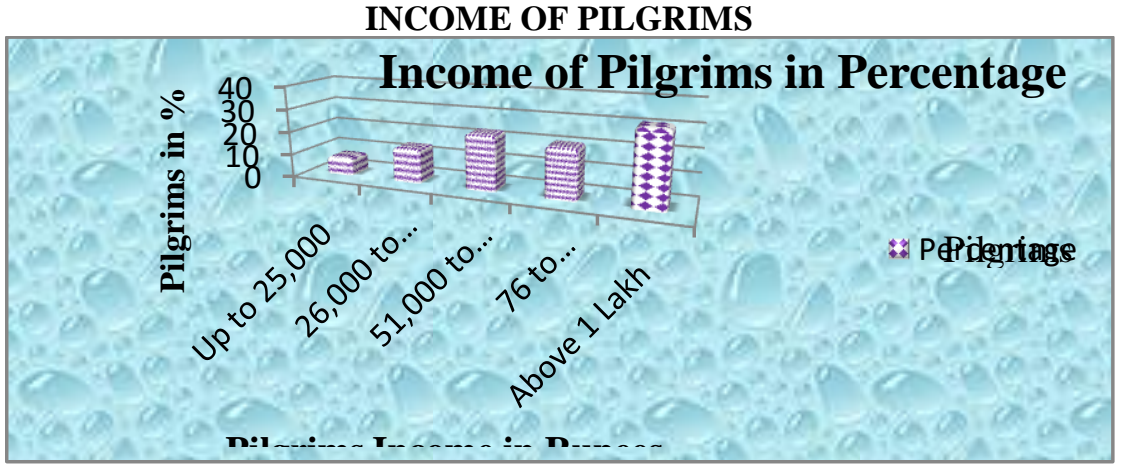


The 23.83 percent pilgrims are involves in to 51 to 75,000 annual income range which is on second position in the income level of pilgrims. The 21.49 pilgrims are noticed in the range of 76 to 100,000 annual income and which is in the third position of income level of shegaon pilgrims. The 14.95 percent are include into the range of 26 to 50,000 and the lowest percent of people are notice in the range between up to 25,000 with 7.94 percent and which is very lowest percent of pilgrims in the all income lave of shegaon pilgrims

XII.

PILGRIMS PURPOSE OF VISIT IN PERCENTAGE

The purpose of visit of pilgrims is analyzed with six category in the following table.

Pilgrims Purpose of visit in Percentage

\begin{tabular}{|l|l|l|l|}
\hline \multicolumn{4}{|c|}{ Purpose of Visit } \\
\hline $\begin{array}{l}\text { Sr. } \\
\text { No }\end{array}$ & \multicolumn{1}{|c|}{ Purpose of Visit } & $\begin{array}{c}\text { No. of } \\
\text { Pilgrims }\end{array}$ & Percentage \\
\hline 1 & Pilgrimage & 463 & 72.11 \\
\hline 2 & Recreation & 70 & 10.9 \\
\hline 3 & To Meet Friend and relatives & 22 & 3.42 \\
\hline 4 & Trade and Business & 41 & 6.38 \\
\hline 5 & Personal Work & 33 & 5.17 \\
\hline 6 & Others & 13 & 2.02 \\
\hline & Total & $\mathbf{6 4 2}$ & $\mathbf{1 0 0}$ \\
\hline
\end{tabular}

.Source: Compiled by Author

PILGRIMS PURPOSE OF VISIT IN PERCENTAGE

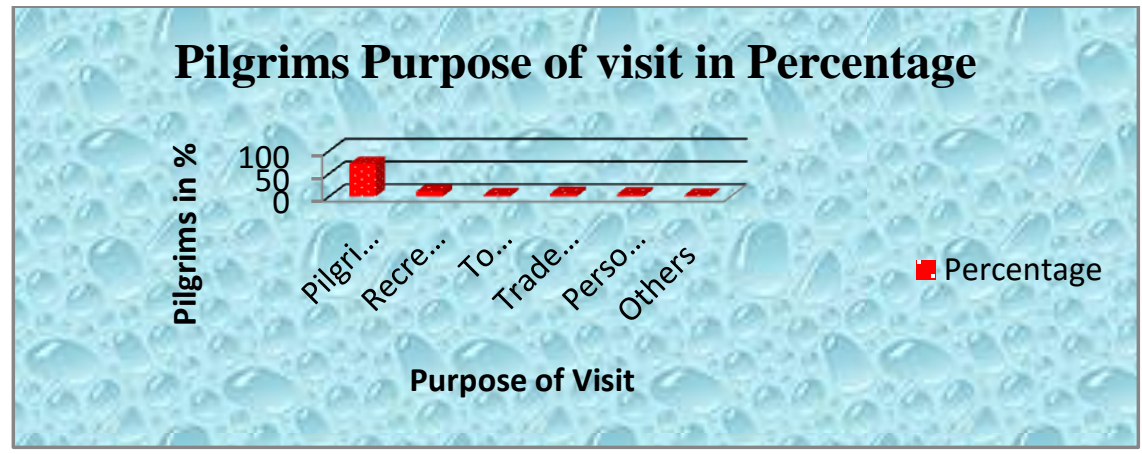

It is clearly indicated that the highest number of the pilgrims have gone to the shegaon for the pilgrimage purpose and which is counted with 72.11 percent. The 10.09 percent pilgrims have visited for the recreation purpose and 3.42 percent pilgrims have gone there for the purpose of to meet friend and relatives and 6.38 for the Trade and Business, 5.17 for the personal work and other 2.02 respectively. It is find that the various number of the pilgrims visiting only for the pilgrimage purpose and 10.9 percent pilgrims visited for the recreation and they are on the second position of purpose of pilgrims visit as well as only 2 percent pilgrims visited for other type of work purpose and they are in the last position in the purpose of visit to the Shegaon.

\section{ACCOMMODATIONS OF PILGRIMS:}

The pilgrims accommodations is the important aspect and which has analyzed with four category in the following table. The Shegaon pilgrim are accommodate into Bhakt Nivas Kendra, Guest house, Hotel and Friends and relative respectively.

XIV. ACCOMMODATIONS OF PILGRIMS

\begin{tabular}{|l|l|l|l|}
\hline \multicolumn{4}{|c|}{ Accommodation of Pilgrims } \\
\hline Sr. No & \multicolumn{1}{|c|}{ Accommodation } & No. Of Pilgrims & Percentage \\
\hline 1 & Bhakt Nivas Kendra & 376 & 58.56698 \\
\hline 2 & Guest House & 139 & 21.65109 \\
\hline
\end{tabular}




\begin{tabular}{|l|l|l|l|}
\hline 3 & Hotel & 102 & 15.88785 \\
\hline 4 & Friends and Relatives & 25 & 3.894081 \\
\hline & Total & $\mathbf{6 4 2}$ & $\mathbf{1 0 0}$ \\
\hline
\end{tabular}

Source: Compiled by Author

ACCOMMODATIONS OF PILGRIMS

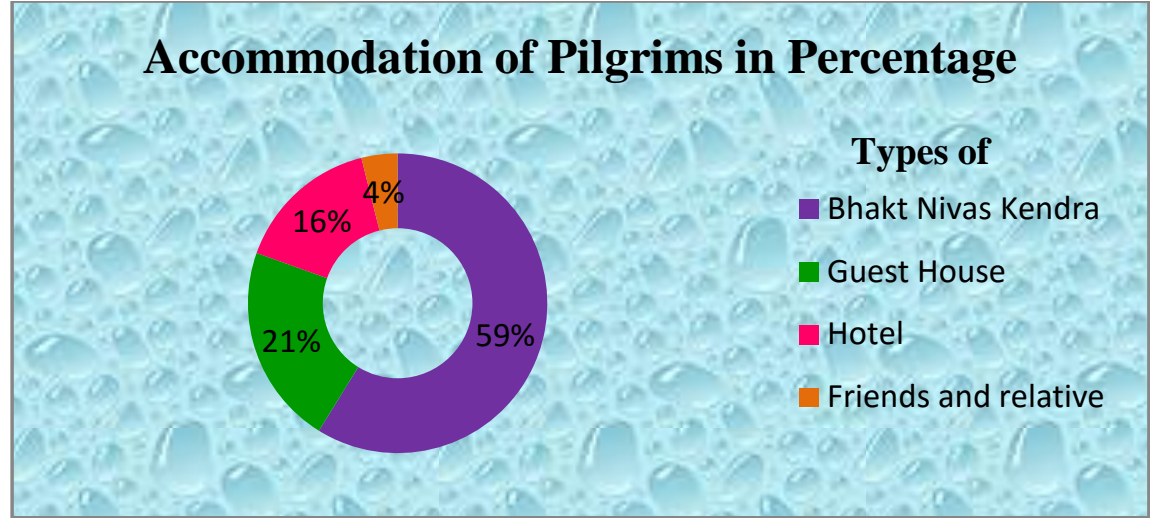

There is very good accommodate facility from the Shri.Gaganan Maharaj Sansathan at Shegaon and which is providing rescannable accommodation to the pilgrims so it is found that the 59 percent pilgrims have accommodate at the Bhakt Nivas Kendra and they are in the first rank of the accommodation of pilgrims. There is some pilgrims have chosen guest house for the accommodation and they are counted with 21 percent, the hotel facility also support to the pilgrims accommodation and which is counted with 16 percent respectively. While four percent of pilgrims have accommodate at their friends and relative and these types of pilgrims noticed with low range.

\section{CONCLUSION}

The present paper is deals with the religious tourism. The religious tourism and pilgrimage tourism are equal concept and meaning of it's is a journey of people with religious belief at religious destination. The present paper focused on pilgrims activity such as their distribution, mode of travel, accommodation, duration of stay, purpose of visit etc. these are aspect have analyzed with geographical method.It is noticed that the large number no of pilgrims are visiting from the Amravati division. The pilgrims are happy with the facilities provided to them from the sanstha. The Authors have contributed in decent manner in studying the pilgrims and various criteria are studied and are presented in graphical and tabular form .

\section{REFERENCES}

[1] M.A.Khan (2005) : Introduction to tourism. Anmol Publications Pvt. Ltd. Daryaganj, New Delhi.

[2] B.S Badan, Harish Bhatt (2007): Regional tourism, Ajay Verma for commonwealth Publishers Daryaganj, New Delhi.

[3] . Bhardwaj, S.M. (1973): Hindu places of Pilgrimage in India- A study in cultural Geography, University of California press Berkeley, Los Angles, London.

[4] Bharati, Aghnanda (1963): Pilgrimage in the Indian Tradition, History of Religions.

[5] Bhatt.B.L. (1977):The Religious Geography of south Asia: Some Reflections, National Geographical Journal of India, Vol-23:PP26-39.

[6] Bhattacharya, A.N. (1961): "Geography and Indian Religion " National Geographer, Vol.4 PP. 12-17.

[7] Chettiar, C.M. Ramchandra (1941) "Geographical Distribution of Religious places in Tamilnadu." Indian Geographical Journal, Vol -16. PP - 42-50.

[8] Sopher, David, E (1968): Pilgrimage Circulation in Gujarat, Geographical Review. Vol, 58,P-217.

[9] V.S Deshmukh (2009)Jejuri : A study in Religious tourism. Ph.D thesis submitted to Shivaji University, Kolhapur. (Unpublished)

[10] Web Sources :-www.mtdc.com, www.google.com 